\title{
The Influence of Open-Ended and STAD Method on the Mathematical Problem- Solving Skills in Terms of Learning Achievement
}

\author{
A. Alman \\ STKIP Muhammadiyah Sorong. Jalan KH. A. Dahlan No. 1 Mariat Pantai, Sorong Papua Barat \\ Email: alman_kuntara@yahoo.co.id, Telp: +628951324409 \\ Received: 31 May 2017; Accepted: 19 June 2017
}

\begin{abstract}
This study is a quasi-experimental research using factorial design. This study aimed at finding the facts that had been resulted from the different influence caused by the use of Open-Ended method and that of STAD method on the students' mathematical problem-solving skills in terms of learning achievement. The learning achievement was categorized into two types namely the high achievement and the low achievement. The population in this study was Grade V students from SD Negeri Serayu. The data were analyzed by ANAVA univariate test. The results of the study were as follows. First, there have been differences on the mathematical problem-solving skills of the students who had been taught using Open-Ended method and those who had been taught using the STAD method. Second, there were also differences in the students' score. For the students who had been taught using the Open-Ended method, the highest post-test average score of their learning achievement was 95.71 while the lowest post-test average score of their learning achievement was 63.92. These students' total average score of learning achievement was 81.04. On the other hand, for the students who had been taught using STAD the highest post-test average score of their learning achievement was 95.50 while the lowest post-test average score of their learning achievement was 70.00. These students' total average score of learning achievement was 89.13 . Third, there has not been any differences between the Open-Ended method and the STAD method.
\end{abstract}

Keyword: Open-Ended method, STAD method, problem-solving skills, learning achievement

How to Cite: Alman, A. (2017). The influence of open-ended and STAD method on the mathematical problemsolving skills in terms of learning achievement. Jurnal Prima Edukasia, 5(2), 112-124. doi:http://dx.doi.org/10.21831/jpe.v5i2.14280

Permalink/DOI: http://dx.doi.org/10.21831/jpe.v5i2.14280

\section{Introduction}

The open-ended or open-problem method is a method that appears based on the openended approach that has been popular in Mathematics in terms of implementation. Openended learning method is one of educational innovative efforts that was first implemented by the experts of Mathematics education in Japan. Principally, the open-ended method is similar to the problem-based learning, a learning method of which the process starts from giving students a certain problem. Open-Ended (OE) as a learning method refers to a view regarding a process whose characteristics are still general; OE institutes, inspires, and reinforces theorybased learning methods.

Becker \& Shimada (2005, p. 1) explain that in teaching method that we call an openended approach an incompleted problem is presented first. The lesson then proceeds by using many correct answers to the given problem to provide experience in finding something new in the process. According to Suyatna in Darmayanti. Putu Laksmi, Putra, \& Suara $(2014$, p. 3), the open-ended method is a learning that implements open problems, which means that the learning process in this method presents problems which have many problemsolving activities (flexibility) and in which the solutions can also be various (multiple answers/fluency).

Setiamihardja \& Kusmiyati (2007, p. 3) mention several matters that can be the reference in creating problems in the open-ended method, namely: (1) problems can be presented through real physical situations so that mathematical concepts might be observed; (2) proving-type test items might be converted in such a way that sutdents can identify the relationship and the characteristics of variables in the related 
Jurnal Prima Edukasia, 5 (2), July 2017 - 113

\author{
A. Alman
}

problems; (3) planes and buildings (geometry) can be presented so that students can establish their conjecture; (4) number or table can be presented so that students can identify mathematical regulations; and (5) concrete problems can be presented under several categories so that students can collaborate the characters of integral number operation.

Thereby, the open-ended method provides opportunities for students to investigate multiple strategies that they believe according to the their capabilities of integrating these problems. The objective is that students' thinking skills in solving mathematical problems can develop maximally through the teaching-learning process.

Many studies show that cooperative learning (Students Team Achievement Division) such as collaborative learning turns out to be more effective than the learning process that a teacher conducts himself. The reason is that students' background and experiences are similar from one to another than the teacher's schemata. Learning methods that make use of group cooperation are not always effective and successful. The Students Teams Achievement Division method can achieve maximum results if a teacher implements five elements as follows: (1) positive interdependence; (2) personal responsibility; (3) meeting; (4) inter-group member communication; and (5) group process evaluation (Hamruni, 2013, p. 217).

Cooperative learning is a learning method that assigns students to establish small groups in a classroom or an environment in which they learn together so that they can improve their confidence individually (Akçay \& Doymuş, 2014, p. 18). Similar definition is also provided by Cohen, Brody, \& Sapon-Shevin (2004, p. 3). Cooperative learning enables all students to cooperate; each student gets experiences and a teacher just needs to identify the student's knowledge and to respect various and different students' learning skills and styles.

Furthermore, Gillies (2003, p. 9) explains that teacher's success in a learning process also depends on how he or she has discussions with their students in order to motivate them in pursuing their interests, how he or she presents one student to another in their interaction, and how he or she has interaction with the colleagues under appropriate manner in socialization.

Thereby, through the Students Teams Achievement Division (STAD) method students can cooperate in one team within the learning process. The learning activities in this method aim at improving students' confidence individually in their socialization so that students can improve their skills and capabilities in solving mathematical problems.

The open-ended method and the STAD method in the learning process altogether present problems in which solutions should be found by students. The open-ended method is an open problem-solving method which has clear context; it has many solutions that might be different in the problem-solving activities yet these solutions head to the same single objective. Learning process using the openended method trains students' thinking pattern and develops their creativity so that eventually the students understand their capabilities well. On the other hand, the STAD method is a main idea that motivates students to mutually support and assist one another in mastering the steps that a teacher has provided.

The steps in the open-ended method are as follows: (a) the open-ended method starts with providing open problem-solving activities to students and these activities are predicted to be accomplished by the students in many ways that result in many answers so that the students' intellectual potentials and experiences will be encouraged within the process of finding new knowledge; (b) the students perform many activities in order to solve the problems that have been given; (c) sufficient time will be provided to the students so that they can explore their problem-solving activities; (d) the students summarize the process of discovery that they have conducted; and (e) the teacher will hold a classroom discussion regarding the problemsolving activities and conclude these activities under his or her guidance (Endriyana, 2011, p. 27). As a comparison, the steps in the STAD method are as follows: (a) the teacher holds a classroom presentation in implementing the learning materials using the method (STAD) during the learning process because this process will help the students in completing their quiz and the score of their quiz will determine that of their team; (b) the team in this method consists of several members, ranging from 4 to 5 people in a group, and the team is the most important feature in this method; (c) a quiz is the final step and after the teacher presents his or her materials and the students present their materials for two or three times the students will complete their quiz individually; (d) Slavin (1995, p. 73) 
states that individual score should be given to the students in order that they achieve the performance objectives in a better and more diligent manner; and (e) there will be a team recognition and here the team will have appreciation in the form of certificate or alike if the mean sore of the team has achieved the criteria that the teacher has set.

In elementary schools, all subjects are integrated into one theme. One of the learning materials that have been integrated to the other learning materials is Mathematics. The Mathematics learning is a subject that should be taught to all educational levels, starting from the elementary ones to the advanced ones (Hendrawan, Suarni, \& Sudiana, 2013, p. 3). Mathematics is the science that can solve problems that students encounter in their daily life by implementing the patters that have been proposed by Polya. According to Polya (Bennett, Burton, \& Nelson, 2012, pp. 4-5), there are four problem-solving steps that might be performed namely: (1) understanding the problems; (2) making plans; (3) executing the plans; and (4) reviewing the plans. Problems are questions that should be answered or be responded. Problems are the situations in which an individual demands something but he or she does not know how to get it. Leiba \& Nachmias (2013, p. 37) stated that problem-solving can be considered as a situation in which students cannot solve the test items using the procedures that they usually implement. Another opinion has also been provided by Van de Walle (Karatas \& Baki, 2013, p. 51) for the same reason; he stated that educating students to be an efficient problem solver is the important role of Mathematics learning. According to Dafid Johnson and Johnson (Thobroni, 2011, pp. 337340), the problem-solving activities can be performed through small groups. Problemsolving that occurs in a learning process is often identified with something complex and difficult, whereas challenging incuriosity can provide problem-solving manners and strategies. According to D'Augustine \& Smith (1992, p. 28 ), problem occurs when an individual want to meet his or her objective but he or she does not know how to meet it. Problem-solving, then, becomes the second part of the process in which the individual wants to meet his or her objective. Bennett et al. (2012, p. 1) stated that exercises using the problem-solving test items will actively develop students' knowledge and skills actively and optimally so that they will not be a learner who heavily depend on the teacher's explanation. Similarly, Chapman, (2005) stated that problem-solving skills is not only important in learning and teaching Mathematics but is also important as the manner of performing something. Pimta, Tayruakham, \& Nuangchalerm (2009, p. 381) also stated that Mathematics is an aid that has not only been benefitted for assisting students in developing their thinking skills but has also been benefitted for developing their fundamental skills in solving their daily problems.

Furthermore, Mathematics will also improve students' thinking skills in solving problems by using appropriate learning methods so that the learning process will not be monotonous and be bored for the students. When the students are bored, they will have difficulties in absorbing the learning materials that have been distributed and especially in solving mathematical problems. Handika and Sutrisno in Sarino (Handika \& Wangid, 2013, p. 86), state that one of the indicators for our low educational quality is that students are less able to solve contextual problems that they deal with. The reason is that the learning process has emphasized on the materials and procedures memorization without referring to the facts in the field.

The decreasing students' motivation during the teaching-learning process is influenced by the monotonous learning activities that have been found on the students' manual and the teachers' manual as well as the students' worksheets.

The problems of low achievement in Mathematics are still found in elementary schools and one of the elementary schools that suffer from such problems is SD Negeri Serayu Yogyakarta. From the results of an interview with one of Grade Five teachers, the researcher found that the learning method that has been implemented still refers to the one that has been written in the teachers' manual namely the book of 2013 Curriculum. The learning steps that have been performed are in accordance with what have been written in the teachers' manual. This matter can be seen from the documents of learning results or the educational reports at the end of a semester; both documents show that there are still students who have low Mathematics score. The Mathematics scores of these students are still below the minimum passing grade that has been set. 


\section{A. Alman}

Such low achievement on Mathematics is caused by the fact that there are several teachers who implement the old or the conventional methods in the Mathematics learning process. The conventional method is a lecturing learning method whose coverage only centers on the teacher. Regarding that this problems should be given top priority, the researcher performed a study about the different influence between the open-ended method and the STAD method on the students' mathematical problem-solving skills in terms of learning achievement. This study then aimed at: (1) identifying the students' mathematical problem-solving skills through the implementation of open-ended method and STAD method; (2) identifying the better method that should be implemented in solving the mathematical problems; and (3) identifying the differences on the mathematical problemsolving skills through the implementation of open-ended method and STAD method.

\section{Method}

The subjects in this study were Grade 5A and Grade 5C students from SD Negeri Serayu Yogyakarta in 2014/2015 Academic Year; Grade 5A consisted of 26 students, while Grade 5B consisted of 24 students. The study was a quasi-experiment using factorial design. In this design, the researcher would like to see the differences between the two groups by implementing the open-ended method and the STAD method. Then, the data gathering technique that the researcher employed was a post-test on the mathematical problem-solving skills. Table 1 displayed the reliability of each method.

Table 1. Alpha Cronbach Value

\begin{tabular}{crcc}
\hline Method & $\boldsymbol{\alpha}$ value & \multicolumn{1}{c}{ N } & Note \\
\hline Open-Ended & 0.739 & 15 & Reliable \\
STAD & 0.744 & 15 & Reliable \\
\hline
\end{tabular}

The data analysis technique that the researcher employed was descriptive statistical analysis. The descriptive analysis was employed in order to describe the situations after the treatment had been administered to each grade according to the view of each independent variable. It should be noted that the effectiveness of mathematical learning might be defined based on the criteria of learning objective achievement shown by the students' passing grade in learning Mathematics. The students were considered meeting the minimum passing grade if the classroom average score was higher than the minimum passing grade itself, namely 60 . On the other hand, a method was considered effective according to the view of students' mathematical achievements if the achievement of their mathematical learning belonged to the "High" category.

The data that had been attained during the study should meet the requirement of assumption test first before being analyzed. The requirement of assumption test that should be met was the normality test using the descriptive statistics through under 0.05 explore; if this requirement had been met, then the data would be considered normally distributed. Furthermore, the homogeneity of both grades was tested using the descriptive statistic using explore. If the significance value that had been attained was greater than 0.05 , the variance matrix of both grades would be homogenous. After passing through the process of assumption test, the researcher continued the analysis to the one-sampled t-test in order to analyze the effectiveness of the two methods according to the view of each independent variable. Meanwhile, the analysis on the difference of effectiveness between the open-ended method and the STAD method was performed using Analysis of Variance (ANAVA) univariate test. The significance value that had been employed in the effectiveness test was 0.05 , while the univariate test was performed using the independent-sampled t-test on significance rate 0.05 . This test was administered in order to see whether the open-ended method or the STAD method that had been more effective.

\section{Results and Discussion}

Result

The results of descriptive statistical analysis data were presented in Table 2 .

Table 2. Description on the Post-Test Results on the Mathematical Problem-Solving Skills using the Open-Ended (OE) Method and the STAD Method

\begin{tabular}{lrr}
\hline \multirow{1}{*}{ Attribute } & \multicolumn{2}{c}{ Method } \\
\cline { 2 - 3 } \multicolumn{1}{c}{ Open-Ended } & STAD \\
\hline Subject (N) & 26 & 24 \\
Mean & 81,04 & 89,13 \\
Standard Deviation & 17,637 & 13,126 \\
Variance & 311,078 & 172,288 \\
Max. Score & 100 & 100 \\
Min. Score & 60 & 60 \\
\hline
\end{tabular}

Based on the results displayed in Table 2, the average score of the post-test for the open- 
ended method was 81.04, while the average score of the post-test for the STAD method was 89.13. On the other hand, the maximum and the minimum score for each grade, respectively, was 100.00 and 60.00 . Then, the criteria of minimum passing grade that had been defined by SD Negeri Serayu, especially for Mathematics, were 60.00 ; as a result, both grades had met the minimum passing grade. The score was categorized into the high one and the low one. The size of post-test data distribution that had been based on the high achievement and the low achievement was presented in Table 3.

Table 3. The Post-Test Distribution Data on the High Achievement and the Low Achievement for the Two Methods

\begin{tabular}{|c|c|c|c|c|}
\hline \multicolumn{2}{|c|}{ Achievement } & Mean & Std. Dev & $\mathbf{N}$ \\
\hline \multirow{3}{*}{ High } & Open-Ended & 95.71 & 8.516 & 14 \\
\hline & STAD & 95.50 & 7.602 & 18 \\
\hline & Total & 95.59 & 7.882 & 32 \\
\hline & Open-Ended & 63.92 & 5.230 & 12 \\
\hline \multirow[t]{3}{*}{ Low } & STAD & 70.00 & 3.286 & 6 \\
\hline & Total & 65.94 & 5.439 & 18 \\
\hline & Open-Ended & 81.04 & 17.637 & 26 \\
\hline \multirow[t]{2}{*}{ Total } & STAD & 89.13 & 13.126 & 24 \\
\hline & Total & 84.92 & 16.007 & 50 \\
\hline
\end{tabular}

Based on the results displayed in Table 3, the post-test data distribution on the problemsolving skills in terms of learning achievement might be classified into two categories, namely the average score of the high achievement group and the average score of the low achievement group. Still based on the same results, the researcher found the following information. First, the students who had earned the high achievement through the implementation of the open-ended method were 14 people with the average score 95.71 and the standard deviation 8.516. On the contrary, the students who had earned the high achievement through the implementation of the STAD method were 18 people with the average score 95.50 and the standard deviation 7.602. The overall number of students who had earned the high achievement through the implementation of both the openended method and the STAD method were 32 people with the average score 95.59 and the standard deviation 7.882. Second, the number of students who had earned the good achievement, both in the high achievement group and the low achievement group, through the implementation of the open-ended method was 26 people with the average score 63.92 and the standard deviation 5.230. On the contrary, the students who had the low achievement through the implementation of the STAD method were 6 people with the average score 70.00 and the standard deviation 3.286. The overall number of students who had low achievement through the implementation of both the open-ended method and the STAD method was 18 people with the average score 65.94 and the standard deviation 5.493. Third, the total number of the students who had the high and the low achievement through the implementation of the open-ended method was 26 people with the average score 81.04 and the standard deviation 17.637. On the other hand, the total number of the students who had the high and the low achievement through the implementation of the STAD method was 24 people with the average score 89.13 and the standard deviation 13.126. The overall number of the students who had the high achievement and the low achievement through the implementation of both the open-ended method and the STAD method was 50 people. The total average achievement score from both methods was 84.92 and the standard deviation was 16.007.

\section{Results of Hypothesis Testing}

The hypothesis that would be tested in this study was there are significant differences in the mathematical problem-solving skills between the students who are treated with the open-ended method and the students who are treated with the STAD method. In this hypothesis testing, the researcher employed the independent- $t$ test. Based on the calculation results from the requirement test which showed that the results of the post-test data from both experimental groups had been normal and homogenous and based on the fact that the number of students in each grade had been different, the researcher employed the onesampled t-test. The results of analysis for the ttest were presented in Table 4 below.

Table 4. Results of Hypothesis Testing

\begin{tabular}{lccccc}
\hline Achievement & $\mathbf{T}_{\text {table }}$ & $\mathbf{T}_{\text {count }}$ & $\mathbf{N}$ & Sig. & Note \\
\hline OE & 1,71 & 22,855 & 26 & 0,00 & $\begin{array}{c}\mathrm{H}_{0} \text { is } \\
\text { rejected }\end{array}$ \\
STAD & 1,71 & 33,264 & 24 & 0,00 & $\begin{array}{c}\mathrm{H}_{0} \text { is } \\
\text { rejected }\end{array}$ \\
\hline
\end{tabular}

Based on the results of analysis that had been attained from the one-sampled t-test with $\mathrm{t}_{\text {coun }} \mathrm{t}=22.855$ and $\mathrm{t}_{\text {table }}=1.71, \mathrm{t}_{\text {coun }} \mathrm{t}>\mathrm{t}_{\text {table }}$ with 


\section{A. Alman}

significance $0.00<0.05$ for the open-ended method and with $\mathrm{t}_{\text {count }}=33.264$ and $\mathrm{tt}_{\text {able }}=1.71$, $t_{\text {count }}>t_{\text {table }}$ with significance $0.00<0.05$ for the STAD method, the researcher found that $\mathrm{H}_{0}$ had been rejected and $\mathrm{H}_{1}$ had been accepted. As a result, the researcher concluded that there were not any differences in terms of influence between the open-ended and the STAD method on the students' mathematical problem-solving skills from the perspective of learning achievement.

The statistical hypothesis testing on this study was performed by the analysis of variance (ANAVA) and the Tukey's test. The analysis of variance was employed in order to test the differences and the interaction of the independent variable to the open-ended method and the STAD method on the dependent variable in the form of learning achievement. The results of analysis by the ANAVA test were performed in Table 5.

From Table 5 that displayed the results of ANAVA analysis, the researcher could provide several explanations as follows. First, in the interaction row it was apparent that there had not been any interaction of the two factors between the method and the achievement. The impact of the method and the achievement was significant. These findings showed the interaction of the two factors between the method and the achievement. These findings also showed that the hypothesis $\mathrm{H}_{0}$ (there has not been any interaction between the openended method and the STAD method) was accepted and that the hypothesis $\mathrm{H}_{1}$ (there has been any interaction between the open-ended method and the STAD method) was rejected. This statement implied that there was not any interaction between the open-ended method and the STAD method toward the students' mathematical problem-solving skills from the perspective of learning achievement. Then, on the method column there had been differences on $\mathrm{F}$ value $=0.851$. This different value implied that the hypothesis $\mathrm{H}_{0}$ (there were differences on the mathematical problem-solving skills between the students that had been taught with the open-ended method and the students that had been taught with the STAD method) was rejected. Therefore, the researcher might state that there were differences on the mathematical problem-solving skills between the students who had been taught with the open-ended method and the students who had been taught with the STAD method. From the post-test data that had been attained, the students who had been taught with the open-ended method did not have significant differences in comparison to those who had been taught with the STAD method. This result might be viewed from the students' average post-test results: $\bar{X}=81.04$ for the open-ended method and $\bar{X}=89.13$ for the STAD method. Second, on the problem-solving achievement row $\mathrm{F}=184.300$; this $\mathrm{F}$ value showed that the null hypothesis $\left(\mathrm{H}_{0}\right)$ which stated that there are not any differences on the mathematical problem-solving skills between the students in the high achievement group and the students in the low achievement group was rejected; in other words, the alternative hypothesis was accepted. Therefore, the researcher might state that there were significant differences on the mathematical problemsolving skills between the students in the high achievement group and the students in the low achievement group. From the post-test data, the average score of the students in the high achievement group was 95.71 while the average score of the students in the low achievement group was 63.92 .

From this analysis, it was confirmed that there was not any interaction between the method and the achievement toward the students' mathematical problem-solving skills from the perspective of learning achievement.

Table 5. ANAVA Test

\begin{tabular}{|c|c|c|c|c|c|c|c|}
\hline \multirow{2}{*}{ Source of Variance } & \multirow{2}{*}{ JK } & \multirow{2}{*}{ dk } & \multirow{2}{*}{ MK } & \multirow{2}{*}{$\mathbf{F}$} & \multicolumn{2}{|c|}{$\mathbf{F}_{\text {table }}$} & \multirow{2}{*}{ Sig. } \\
\hline & & & & & 0.05 & 0.01 & \\
\hline Achievement (inter-column) & 9254.109 & 1 & 9354.109 & 184.300 & 4.04 & 7.19 & 0.000 \\
\hline Method (inter-row) & 43.186 & 1 & 43.186 & 0.851 & 4.04 & 7.19 & 0.361 \\
\hline Errors in groups & 373126.000 & 47 & 50.755 & & & & \\
\hline Total & 12555.680 & 50 & & & & & \\
\hline
\end{tabular}


Jurnal Prima Edukasia, 5 (2), July 2017 - 118

\author{
A. Alman
}

Table 6. Tukey's Post-Test Analysis

\begin{tabular}{clrrr}
\hline \multicolumn{1}{c}{ (I) Group } & \multicolumn{1}{c}{$(\mathbf{J})$ Group } & Mean Difference (I-J) & Std. Error & Sig. \\
\hline \multirow{2}{*}{ OE High Achievement } & OE Low Achievement & $31.798^{*}$ & 2.770 & 0.00 \\
& STAD Low Achievement & $25.714^{*}$ & 3.435 & 0.00 \\
\multirow{2}{*}{ OE Low Achievement } & OE High Achievement & $-31.798^{*}$ & 2.770 & 0.00 \\
& STAD Low Achievement & $-31.583^{*}$ & 2.624 & 0.00 \\
\multirow{2}{*}{ STAD High Achievement } & OE Low Achievement & $31.583^{*}$ & 2.624 & 0.00 \\
& STAD Low Achievement & $25.500^{*}$ & 3.319 & 0.00 \\
& OE High Achievement & $-25.714^{*}$ & 3.435 & 0.00 \\
& STAD Low Achievement & $-25.500^{*}$ & 3.319 & 0.00 \\
\hline
\end{tabular}

Table 7. The Homogenous Subsets from the High Achievement Group and the Low Achievement Group on the Open-Ended (OE) Method and the STAD Method

\begin{tabular}{lrrrr}
\hline \multicolumn{1}{c}{ Group } & \multirow{2}{*}{$\mathbf{N}$} & \multicolumn{3}{c}{ Subset for alpha = 0,05 } \\
\cline { 3 - 5 } & 12 & $\mathbf{1}$ & 63.92 \\
\hline OE Low Achievement & 6 & & 70.00 & \\
STAD Low Achievement & 14 & & & 95.710 \\
OE High Achievement & 18 & & 0.207 & 95.500 \\
STAD High Achievement & & & 1.000 \\
Sig. & &
\end{tabular}

\section{Further Test (Tukey's Test)}

Both average scores on the mathematical problem-solving skills from the non-identical subjects were tested using the Tukey's test after the ANAVA test had been performed; the objective of performing this Tukey's test was to measure the different sample from the subjects. The Tukey's test was conducted in order to identify which group had been different and had the best and the most effective mathematical problem-solving skills. The results of Tukey's test were displayed in Table 6.

Based on the results that had been displayed in Table 6, the researcher's analysis on the mean difference column show the sign "*” on the number from each row. This sign showed that the mean differences had been significant. On the other hand, based on the results that were displayed in Table 7 , the researcher would identify which group or which subset that had insignificant mean difference on the average score. In the subset 1 , it was apparent that the mean of the group that had only used the open-ended method was 63.92; as a result, the researcher might state that the average mathematical problem-solving skills using the open-ended method had been different than those using the other method namely the STAD method. These differences might be seen on the columns of subset 1 and subset 2; these columns had different values on the low achievement group and the value of the column on the subset 2 was different than that of the column on the subset 3 . As a result, the first hypothesis which stated that there are significant differences on the mathematical problemsolving skills that have been caused by the differences between the open-ended method and the STAD method was accepted.

On Table 7, it was apparent that the highest average score of mathematical problemsolving skills was 95.71 for the STAD method, whereas the highest average score of mathematical problem-solving skills was 81.04 for the open-ended method. Thereby, the researcher might conclude that the learning process by means of the STAD method had been better or been more effective in improving the students' mathematical problem-solving skills.

In this case, the one-factor ANAVA test was employed in order to test whether there were significant differences on the mathematical problem-solving skills from the perspective of learning achievement. follows:

The hypotheses for this case were as

$\mathrm{H}_{0}=$ There are not any differences on the average score of mathematical problemsolving skills between the students who have been taught with the open-ended method and those who have been taught with the STAD method.

$\mathrm{H}_{1}=$ There are differences on the average score of mathematical problem-solving skills between the students who have been taught with the open-ended method and those who have been taught with the STAD method. 
Based on the students' average score of mathematical problem-solving skills, the researcher displayed the following results in Table 8.

Table 8. The Data of the Differences on the Mathematical Problem-Solving Skills between the Students Who Had been taught with the Open-Ended Method and Those Who Had been taught with the STAD Method and Their Relationship to the Students' Achievement

\begin{tabular}{cccc}
\hline \multicolumn{2}{c}{ Grade Achievement } & \multicolumn{2}{c}{ Grade Post-Test } \\
\hline $\begin{array}{c}\text { Score } \bar{X} \\
\text { Va }\end{array}$ & $\begin{array}{c}\text { Score } \bar{X} \\
\text { Vc }\end{array}$ & $\bar{X}_{\text {M. }}$ & $\bar{X}_{\text {M. }}$ \\
\hline $\mathbf{8 5 . 1 5}$ & $\mathbf{7 4 . 2 5}$ & $\mathbf{8 1 . 0 4}$ & STAD \\
\hline
\end{tabular}

Based on the results displayed in Table 8, the students' average achievement score before the treatment using the two methods had been implemented was 85.15 for Grade VA and 74.25 for Grade VC. After the treatment using the two different methods, namely the open-ended method and the STAD method, had been administered on the students' mathematical problem-solving skills, the average post-test score for the grade that had been treated with the open-ended method was 81.04 and the average post-test score for the grade that had been treated with the STAD method was 89.15. The two different post-test scores implied that there were differences between the learning process that made use of the open-ended method and the learning process that made use of the STAD method. This statement was based on the average post-test score that each grade had attained. From the data that had been attained from the implementation of both methods, the researcher conclude that the STAD method had been very fit for implementation by teachers in the mathematical problem-solving learning process.

\section{The Significance Test for the Influence from the Interaction on the Mathematical Problem- Solving Skills between the Open-Ended (OE) Method and the STAD Method to the Learning Achievement}

The hypothesis testing by means of ANAVA analysis was intended to identify the interaction between the two factors. This test was also intended to identify whether there had been significant relationship between the two factors or not. In this case, the researcher would test whether there had been significant influence of interaction on the mathematical problem- solving skills that had been caused by the openended method and the STAD method from the perspective of learning achievement.

The hypotheses for this case were as follows:

$\mathrm{H}_{0}=$ There was not any significant influence of interaction on the mathematical problemsolving skills between the open-ended method and the STAD method from the perspective of learning achievement.

$\mathrm{H}_{1}=$ There has been any significant influence of interaction on the mathematical problem-solving skills between the openended method and the STAD method from the perspective of learning achievement.

The decision-making was based on the following probability value: (1) if the significance $\mathrm{p}>0.05$ then the $\mathrm{H}_{0}$ will be accepted; and (2) if the probability $<0.05$ then $\mathrm{H}_{0}$ will be rejected.

From the table of test of between subject effects, it was apparent that there was not any interaction between the method and the achievement. This finding implied that the significance between the open-ended method and the STAD method from the perspective of learning achievement had been rejected.

\section{Discussions}

The results of this study have discussed the influence of each independent and dependent variable on the Grade V students of SD Negeri Serayu that becomes the experimental classes for the implementation of the open-ended method and the STAD method. Both experimental classes turned out to be effective in improving the mathematical problem-solving skills. The reason comes from several factors. The first factor is related to the facilities that the public elementary school has provided such as computer/laptop, projector, student's manual, student's worksheet, and comfortable learning rooms equipped with fans. In addition to the facilities that have been provided, within the teaching-learning process by means of the experimental method the teachers always allocate the time that has been more appropriate to the assigned time; however, this more appropriate time is used mainly for discussing and answering the exercise questions that have been provided by the teachers. The teachers do not directly answer the exercise items that the students have been completing, especially when they find the difficult ones. The results of the 
exercise items that the students have completed are directly distributed to them in order that they can identify their respective skills both individually and cooperatively. By doing so, the students will understand their errors.

This study had two experimental classes namely Grade VA as the experimental class I that was taught with the open-ended method and Grade VC as the experimental class II that was taught with the STAD method. In this study, the researcher has found three matters from the analysis toward the results namely the influence from the open-ended method to the mathematical problem-solving skills from the perspective of learning achievement, the influence from the STAD method to the mathematical problem-solving skills from the perspective of learning achievement, and the differences on the influence between the openended method and the STAD method to the mathematical problem-solving skills from the perspective of learning achievement. A more elaborate explanation on the three matters will be provided in the following sections.

The first matter is the influence from the open-ended method to the mathematical problem-solving skills from the perspective of learning achievement. Based on the results of the study, it turns out that learning by means of the open-ended method has been effective from the perspective of learning achievement. Within the learning process that makes use of the openended method, the students are provided with freedom and opportunities to share their ideas based on the preliminary knowledge that they have in order to find the concepts of the learning materials that they want to study; through this method, the teacher only transfers the knowledge to the students. In this situation, the students are exercised to think critically within the learning process so that they will master the problem-solving skills that the teacher transfers. The process of implementing the open-ended method principally sets a high priority on how to find the results instead of the results themselves. The results of data analysis using SPSS 21.0 for Windows show that the results that have attained is $t_{\text {count }}=23.428$. In relation to the testing criteria, $t_{\text {count }}>t_{\text {table }}=23.428$; as a result, $\mathrm{H}_{0}$ is rejected. Therefore, the researcher can conclude that the students' average mathematical problem-solving skills measured by the implementation of the open-ended method are 81.04. In other words, the open-ended method has been more effective in improving the students' mathematical problem-solving skills from the perspective of learning achievement.

The second matter is the influence from the STAD method to the mathematical problemsolving skills from the perspective of learning achievement. Based on the results of this study, it turns out that the learning process by means of the STAD method has also been effective from the perspective of learning achievement. Within the learning process that makes use of the STAD method, the students are provided with the assignments by the teacher and they have to solve the problems in the assignments within the sufficient time in order to discuss these problems with their teammates. Within the group discussion, the students help their teammate from one to another. They are teaching the problems to the teammates who have not attained complete understanding toward the problems. After the overall group members have attained the full understanding, they present the results of their group discussion in front of the class. The teacher pays attention to the results that have been presented by each student who represents their group and the results of this presentation are written on the board. Then, the teacher gives an award to the students in the form of motivating appreciation especially to those whose team has met the criteria of the score that have been set. In addition to the motivating appreciation, the teacher also gives 20 percent point improvement to the students whose score has been higher than the criteria. This additional point can improve the students' enthusiasm in attaining higher learning achievement.

The results of data analysis using SPSS 21.0 for Windows show that $t_{\text {count }}=33.264$. In relation to the testing criteria, $t_{\text {count }}>t_{\text {table }}=$ 33.264; as a result, $\mathrm{H}_{0}$ is rejected. Therefore, the researcher can conclude that the students' average mathematical problem-solving skills measured by the implementation of the STAD method are greater than 89.13. In other words, the STAD method has been more effective in improving the mathematical problem-solving skills from the perspective of learning achievement in comparison to the open-ended method.

The third matter is the differences on the influence between the open-ended method and the STAD method to the mathematical problemsolving skills from the perspective of learning achievement. The implementation of both the open-ended method and the STAD method has 
equally been effective to the mathematical problem-solving skills. Both methods that have been implemented do not display any differences in terms of effectiveness from the perspective of learning achievement. However, in terms of the students' average score and the percentage of the students who have met the minimally good criteria, the STAD method has been more effective.

Based on the results of the high achievement group and the low achievement group in the implementation of the open-ended method, the average achievement score of the high achievement group in the open-ended method treatment is 95.71 and the average achievement score of the low achievement group in the open-ended method treatment is 63.92; meanwhile, the total average achievement score in the open-ended method treatment is 81.04. On the other hand, the students' average score and presentation score in the STAD method treatment have met the minimally good criteria. Based on the results of both the high achievement group and the low achievement group in the STAD method treatment, the average achievement score of the high achievement group is 95.50 and the average achievement score of the low achievement group is 70.00; meanwhile, the total average achievement score in the STAD method treatment is 89.13. As a result, the researcher can conclude that there have been differences in terms of effectiveness between the open-ended method and the STAD method on their implementation to the mathematical problemsolving skills from the perspective of learning achievement.

\section{The Results of Hypothesis Testing and the Post- Test to the Mathematical Problem-Solving Skills from the Perspective of Learning Achievement}

First of all, the researcher will discuss the results of the first hypothesis testing. There are significant differences in terms of students' achievement on the mathematical problemsolving skills between the open-ended method and the STAD method.

In the first hypothesis testing, the researcher concludes that there are significant differences regarding the achievement on the mathematical problem-solving skills that have been caused by the differences between the open-ended method and the STAD method and by the learning achievement. The learning process is still common, tends to be static, and still centers on the teacher. The learning process provides less challenge to the students in order that they can positively compete from one to another. The teacher should have more innovations in the classroom so that the students can absorb the learning materials well and effectively. The open-ended method and the STAD method provides wide space for students to see the skills both individually and collaboratively by holding a competition-like discussion in which they can share different opinions. As a result, the students can gain new knowledge and insight within the process of the group discussion and the classroom discussion.

The above situation is similar to the results of the Hypothesis 1: in overall there are quite significant differences between the students who learn through the implementation of the open-ended method and those who learn through the implementation of the STAD method with $\mathrm{F}=0.851$ and $\mathrm{p}=0.361$. Because the probability is greater than $0.05(\mathrm{p}>0.05), \mathrm{H}_{0}$ is accepted. Thereby, the first hypothesis which states that there are significant differences on the mathematical problem-solving skills that have been caused by the differences between the open-ended method and the STAD method is rejected. Each of these methods provides different results and, therefore, the researcher continues the analysis by performing the ANOVA advanced test namely the Tukey's test. From the results of the Tukey's test, it is also apparent that the implementation of the openended method and the STAD method provides effective results on the mathematical problemsolving skills.

Second, the researcher would like to discuss the results of the second hypothesis testing. There are significant differences regarding the mathematical problem-solving skills between the open-ended method and the STAD method from the perspective of learning achievement.

In the second hypothesis testing, the researcher concludes that there have been significant differences regarding the mathematical problem-solving skills between the students who are treated with the open-ended method and those who are treated with the STAD method from the perspective of learning achievement.

According to the second hypothesis and based on the table of test of between subject effects, it is apparent that F-count is 184.3000 with significance at 0.00 . This finding shows 
Jurnal Prima Edukasia, 5 (2), July 2017 - 122

\section{A. Alman}

that the significance $\mathrm{p}<0.000$; as a result, the $\mathrm{H}_{0}$ is rejected. The rejection implies that the average score of both methods in relation to the mathematical problem-solving skills is nonidentical. Thereby, the second hypothesis which states that there have been significant differences regarding the mathematical problemsolving skills that have been caused by the differences of the achievement is accepted.

In other words, the second hypothesis which states that there have been significant differences regarding the mathematical problemsolving skills that are caused by the different level of achievement is accepted.

Third, the researcher would like to discuss the results of the third hypothesis testing. In the third hypothesis testing, the researcher did not find the influence of the significant interaction between the mathematical problem-solving skills and the open-ended method, the STAD method, and the learning achievement.

According to the second hypothesis and based on the table of the test between subject effects and the graphic of interaction between the open-ended method and the STAD method, the researcher did not find the $\mathrm{F}$ value. This statement shows that the significance is greater than 0.05 ( $\mathrm{p}>0.05)$ and, therefore, the $\mathrm{H}_{0}$ is rejected. The rejection implies that there is not any interaction between the mathematical problem-solving skills and the open-ended method, the STAD method, and the learning achievement.

In the third hypothesis testing, the researcher concludes that there is not any signification interaction of influence regarding the mathematical problem-solving skills that has been caused by the open-ended method and the STAD method with the learning achievement.

Because the methods that have been implemented and the students' achievement that has been displayed do not provide sufficient influence to the students' mathematical problem-solving skills, and based on the results of the statistical tests also, the researcher concludes that there is not any significant influence of interaction regarding the mathematical problem-solving skills between the open-ended method and the STAD method from the perspective of learning achievement. As a result, the third hypothesis which states that there is not any significant interaction of influence regarding the mathematical problemsolving skills between the open-ended method and the STAD method from the perspective of learning achievement is accepted.

\section{Conclusions and Suggestions}

\section{Conclusions}

Based on the results of the study and the discussions above, there are several matters that can be concluded as follows. First, there are differences of the influence on the students' mathematical problem-solving skills between the open-ended method and the STAD method from the perspective of learning achievement. These differences show that the $\mathrm{F}$ value is 0.851 and the significance is 0.00 . The statement implies that $\mathrm{H}_{0}$ is rejected and $\mathrm{H}_{1}$ is accepted because $0.00<0.05$ and that there are differences between the open-ended method and the STAD method from the perspective of learning achievement. The differences between the two methods show that the method that will be more appropriate for implementation in the mathematical problem-solving skills is the STAD one. Second, the differences on the mathematical problem-solving skills between the students who have been treated with the open-ended method and the students who have been treated with the STAD method imply certain matters. The average score of the openended method-based high achievement group is 95.71 while that of the open-ended methodbased low achievement group is 63.92. On the other hand, the average score of the STAD method-based high achievement group is 89.13 while that of the STAD method-based low achievement group is 70.00 . Then, the total average score of of the open-ended method for the mathematical problem-solving skills is 81.04, while that of the STAD method for the mathematical problem-solving skills is 70.00 . From the data that have been attained, the highest average score in the open-ended method shows that the open-ended method very fit for implementation to the STAD method-based low achievement group and, conversely, the highest achievement score in the STAD method shows that the STAD method is very fit for implementation to the open-ended method-based low achievement group. Third, there has not been any interaction between the open-ended method and the STAD method to the mathematical problem-solving skills from the perspective of learning achievement. The absence of such interaction implies that $F$ value is 184.300 and significance is 0.00 . Since the 
significance $0.00<0.05$, and based on the fact the table of tests of between subject effects along with the graphic of interaction between both methods show that significance is lower than 0.05 , the second hypothesis $\left(\mathrm{H}_{1}\right)$ is rejected. In other words, there has not been any interaction between the open-ended method and the STAD method on the students' mathematical problem-solving skills from the perspective of learning achievement at the significance 0.00 .

Suggestions

Looking at the above conclusions, the researcher would like to propose several suggestions as follows. First, from the perspective of learning achievement the learning using STAD method for teaching the mathematical problem-solving skills can also be applied to the learning process of other subjects. Second, the Mathematics learning process using the open-ended method is not always effective. This ineffectiveness has been confirmed by the results of this study. Therefore, the teachers are suggested that they implement a learning method that pays attention to the situations and the conditions within the learning process. The teachers should allocate some time for the students to ask questions and to hold discussions in order to solve their problems independently and openly. The teachers should also not prioritize the learning results; instead, the teachers should prioritize the learning process. Instead of discussing directly the exercise items, the teachers can distribute the results of the students' exercise items or groupworks so that they know the their errors. Last but not the least, in the future studies the researcher would like to expect that this study can serve as a reference for the implementation of similar learning models and instruments. This might be pursued by designing research instruments of mathematical problem-solving skills that contain the elements of improving mathematical skills.

\section{References}

Akçay, N. O., \& Doymuş, K. (2014). The of different methods of cooperative learning model on academic achievement in physics. Journal of Turkish Science Education, https://doi.org/10.12973/tused.10124a)

Becker, J. P., \& Shimada, S. (2005). The openended approach: a new proposal for teaching mathematics. Reston, Virgina: National Council of Teachers of
Mathematics.

Bennett, A. B., Burton, L. J., \& Nelson, L. T. (2012). Mathematics for elementary teachers: a conceptual approach. New York, NY: McGraw-Hill.

Chapman, O. (2005). Constructing pedagogigal knowledge of problem solving: Preservice mathematics teachers. In International Group for the Psychology of Mathematics Education (Vol. 2, pp. 225-232). Cape Town: International Group for the Psychology of Mathematics Education. 35 Aandwind Street, Kirstenhof, Cape Town, 7945, South Africa. Tel: +27-21-7153559; Fax: +27-88-021-715-3559; e-mail: info@igpme.org; Web site: http://igpme.org. Retrieved from http://igpme.org

Cohen, E. G., Brody, C. M., \& Sapon-Shevin, M. (2004). Teaching cooperative learning: The challenge for teacher education. New York, NY: State University of New York Press.

D'Augustine, C. H., \& Smith, C. W. (1992). Teaching elementary school mathematics. Ohio University, Athens: HarperCollins Publishers.

Darmayanti. Putu Laksmi, Putra, M., \& Suara, I. M. (2014). Model open ended berbasis reinforcement berpengaruh terhadap hasil belajar IPS siswa kelas V SDN 18 Dangin Puri Denpasar Utara. MIMBAR PGSD, 2(1). Retrieved from http://ejournal.undiksha.ac.id/index.php/JJ PGSD/article/view/3020/2504

Endriyana, N. (2011, July 30). Perbandingan antara pendekatan open ended dan problem posing dalam pembelajaran matematika materi pokok geometri terhadap kemampuan berpikir kreatif dan motivasi belajar siswa SMA/MA NW Narmada. Universitas Negeri Yogyakarta. Retrieved from http://eprints.uny.ac.id/40355/

Gillies, R. M. (2003). Cooperative learning: Integrating theory and practice. London: SAGE Publications. Retrieved from https://books.google.co.id/books/about/Co operative_Learning.html?id=Oh8ZYAPU A $4 \mathrm{kC} \&$ redir_esc $=\mathrm{y}$

Hamruni. (2013). Pembelajaran berbasis edutainment: landasan teori dan metodemetode pembelajaran aktif- 
menyenangkan (PAIKEM). Yogyakarta: Fakultas Ilmu Tarbiyah dan Keguruan UIN Sunan Kalijaga Yogyakarta.

Handika, I., \& Wangid, M. N. (2013). Pengaruh pembelajaran berbasis masalah terhadap penguasaan konsep dan keterampilan proses sains siswa kelas V. Jurnal Prima Edukasia, $\quad 1(1), \quad 85$. https://doi.org/10.21831/jpe.v1i1.2320

Hendrawan, K. A. D., Suarni, N. K., \& Sudiana, I. W. (2013). Pengaruh metode problem solving terhadap hasil belajar matematika siswa kelas V SD gugus VII Kecamatan Tejakula. MIMBAR PGSD, I(1). Retrieved from http://ejournal.undiksha.ac.id/index.php/JJ PGSD/article/view/1426/1287

Karatas, I., \& Baki, A. (2013). The effect of learning environments based on problem solving on students' achievements of problem solving. International Electronic Journal of Elementary Education, 5(3), 249-268. Retrieved from http://files.eric.ed.gov/fulltext/EJ1068620. pdf

Leiba, M., \& Nachmias, R. (2013). Assessing mathematical problem solving behavior in web-based environments using educational data mining. In Proceedings of the Chais conference on instructional technologies research 2013: Learning in the technological era (pp. 44-52). Raanana: The Open University of Israel. Retrieved from http://www.openu.ac.il/innovation/chais2 013/download/a2_1.pdf

Pimta, S., Tayruakham, S., \& Nuangchalerm, P. (2009). Factors influencing mathematics problem solving ability of sixth grade students. Journal of Social Sciences, 5(4), 381-385. Retrieved from http://files.eric.ed.gov/fulltext/ED506983. pdf

Setiamihardja, R., \& Kusmiyati, K. (2007). Pendekatan open ended dalam pembelajaran matematika di sekolah dasar. Jurnal Pendidikan Dasar, 8. Retrieved from http://file.upi.edu/Direktori/JURNAL/PE NDIDIKAN_DASAR/Nomor_8Oktober_2007/Pendekatan_Open_Ended_ dalam_Pembelajaran_Matematika_di_Sek olah_Dasar.pdf

Slavin, R. E. (1995). Cooperative learning: Theory, research, and practice. Sydney: Allyn and Bacon.

Thobroni, M. (2011). Belajar \& pembelajaran: Pengembangan wacana dan praktik pembelajaran dalam pembangunan nasional. Yogyakarta: Ar-Ruzz Media. 